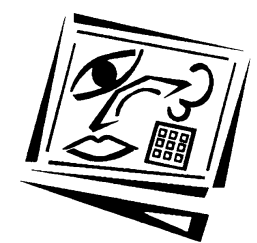

\title{
ICT use by journalism professors in Colombia
}

\author{
Elías Said Hung \\ Fundación Universidad del Norte
}

\begin{abstract}
This article analyses how journalism professors at Colombian universities use information and communications technologies (ICT) in their teaching. Survey data was obtained during the first trimester of 2009 from 63 professors in journalism departments and from a total of 865 professors who are affiliated with journalism departments at 29 universities that belong to the Colombian Association of Journalism Departments and University Programs. These professors have, until now, replicated traditional teaching methods when employing currently available technological resources. The article discusses the factors that influence the teaching uses of ICT and the implementing of pedagogical strategies in the classroom. The results help define the profiles of professors in academic programs in which ICT use is limited, and factors such as investment of time and resources which determine the productive use of ICTs, as well as the implementation of pedagogical models related to new teachinglearning opportunities in the classrooms at Colombian universities.
\end{abstract}

\section{Introduction}

The transformations generated by the ICTs during the advent of the information and knowledge society place us in a frame of accelerated changes in the generation of information channels, the construction of knowledge, and in the self-references at individual and collective level which many experiment with in their communicative maps (Said, 2009a; 2009b).

It is within this process characterised by the Blog Bang (Flores, 2008) or the peak of virtual scenarios, the consolidation of the Bit Generation (Sartori 2002) and the exponential growth of communications linked to the Net Society (Castells, 2006) where the education of future journalists increasingly requires a teaching context that promotes and stimulates new modalities of digital inclusion. And this must be so, in order to guarantee the maximum use of ICTs in their journalistic activities in a context where a new model of communication is appearing (Sotelo \& Sierra, 2009), influenced by the advent of new tools (Web 2.0, among others) and technological supports (mobile phones, PDA and others) coming from the new epistemological statute of journalism in the existing digital ecosystem (Ferreras, 2009; Larrondo, 2009; Mirón, 2007; Haber, 2005).

If we start with the thesis that the media must be understood as social media and not only as technical media, the Internet offers great scope to create a series of changes in the content delivered by traditional media (Palomo, 2004). In the debate linked to the process of digital transition, the digital scenarios should also be transformed in the main spaces for this process of communicative transformation to take place. This includes higher education and academic staff as key actors in the formation of the new 
generation of journalists required by the current digital environment. The educational and organisational context should be flexible, facilitating mobility and collaborative scenarios for communication students, to promote the interpretation of information and the generation of local knowledge (Unión Europea, 2009, p. 1; Ministerio de Educación Cultura y Deporte de España, 2003, p. 2)

This is where ICTs serve as resources that can be used to achieve this new horizon for institutions of higher learning in the training of new professionals, in which the concept of users, which was initially promoted by Simon (1955) and used by Fiske \& Tailor (1991), for example, in the field of socio-cognitive psychology, shall give way to the concept of social actors from a constructivist point of view (Goffman, 1974; Lamb \& Kling, 2003), whereby individuals participate in the process of creating and redesigning the social structure, in which the digital inclusion process is inserted through the interaction that arises from the use of ICTs with other members of society.

For this reason, in this article, we try to respond to the following questions: What is the technological profile of journalism professors in this country? How and to what extent are ICTs used in pedagogical activities? What socio-demographic factors and issues of academic and institutional standing influence the use and level of use of ICTs in teaching activities? In order to answer these questions, in this article, we will present and analyse the results obtained in the study titled Cyber journalism from Journalism Faculties in Colombia, completed by the author during the second semester of 2009.

\section{From the literature-based instruction model to the hypermedia instruction model}

As Westera (2004) states, "New technologies offer many promises of improvement in the quality and efficiency of educational services." ICTs have brought innovation in education, a diverse and complex topic, for it involves the development of new reference points and models for administration, pedagogy, and knowledge management, which represent a departure from the traditional perspectives that remain in many places of higher education. These traditional views can interfere with the development of hybrid learning processes that combine "different educational situations - online and classroom learning - and different educational mechanisms both at a technological level and in terms of activity types - with the aim of creating the adequate learning environment" (Rodriguez \& Escofet, 2006).

Within these transformations of scenarios for hybrid learning, the professors of communication programs become key actors at the moment of achieving the change of traditional perspectives in the context of higher learning scenarios. It is important for them to advance in the process of acquisition of competences that allow them the technological appropriation for the exercise of their pedagogical functions.

The growth of ICT has brought along new reference points. These new concepts include, among others, flexibility, mobility, the creation of new types of professor portfolios, and increased efficiency in the use of pedagogical materials through ICTs (Barberá et al, 2004), as well as a new role for professors as stimulators or as more experienced "trainers" who provide guidance in identifying, gaining access to, and creating knowledge through multimedia and hypertext resources, which can now be used at many institutions of higher education (Landow, 2008) for the purpose of using skills in hypermedia learning environments (Song, 2002; Kuiper, Volman \& Terwel, 2005). The impact of ICT use is evidenced by the transformation described below: 
...the traditional role of the teacher as the 'fountain of knowledge' must be reconsidered as massive amounts of information are readily accessible on the Internet (...) With the continued emergence of new technologies, learning will be less about knowledge residing in the head and more about learning the pathways to knowledge (Frechette, 2002).

The growth in the use of ICTs has had repercussions in the way knowledge circulates and has brought about changes in classical pedagogical models, which are based on literary teaching. These new dynamics are encountering a new context in which students are self-driven and free to make choices thanks to the growing incorporation of ICTs in all contexts of social interaction.

A new generation of students has emerged. These students are comfortable with multimedia and hypertexts. They are capable of acquiring and accumulating knowledge on their own. They are used to reading and writing in online forums. This reveals that the increased use of ICTs in institutions of higher learning is bringing about a new kind of student who is more active, constructive, and responsible when it comes to "accessing information, organizing it, and deriving meaning from it" (Jonassen \& Grablinger, 1990). Therefore, it is necessary to reformulate not only the pedagogical model, but also the approach to ICTs and the skills that professors should have in order to bring out the best of this new kind of student who is a member of the web generation or e-generation.

\section{The professor's classroom role in skills acquisition by students}

From a constructivist and socio-cultural perspective of teaching, a teacher must not simply use classical strategies for evaluating and supporting students. Instead, the teacher must promote more systematic and continuous mechanisms aimed at enhancing the students' independence in teaching-learning processes (Coll, Mauri \& Onrubia, 2006). Therefore, ICT advancements could be viewed as resources that serve to broaden the range of the instructor portfolios that are normally offered at our universities (mainly oriented towards assessment and evaluation of the learning processes). This has given rise to new practices, whereby the professor works with students in order to compile the best work product. Likewise, these dynamics have brought about greater integration and more efficient use of professors' interdisciplinary materials, which they are unable to use in certain cases due to lack of time and insufficient collaboration with many colleagues.

Hypertexts bring together interrelated contents. These shall serve to promote collaborative and interactive online spaces as well as new teaching dynamics that are closer to the image of the trainer, which was presented at the beginning of this text. Therefore, hypertext culture or the integration of interlinked contents as well as the promotion of virtual interactive collaborative scenarios and new teaching dynamics, closer to the image of the trainer could open the space for the promotion of a pedagogical context at the higher education level from the professors who teach at this level. This will not contribute to perpetuating existing deficiencies at the social level, but on the contrary, allow professors to promote mechanisms for the social development of our people by enabling students to become more autonomous, flexible and able to establish individually, interrelation dynamics in the different areas of knowledge linked with their profession. 
The use of ICT resources may foster the development of a set of skills tailored to classroom dynamics, as indicated in Dale's Cone of Learning (Dale, 1954; Molenda, 2003; San Jose State University, 2004), according to which the skills gained by teachers and students through description, explanation, and analysis are previously determined by a series of activities they carry out through both traditional modes of communication as well as new channels brought along by the advancement of ICTs. This has brought a set of skills that contribute to students' processes of understanding their social surroundings, both inside and outside the classroom. Through this process of identifying the complexity in these digital channels through which skills are acquired, technological advancement may help create new classroom contexts in which students gain relevant skills. This is possible to the extent that students are able to make use of multimedia and hypermedia tools that are created through the application of ICTs, and the promotion of online venues that enhance learning processes in each class and during the professors' assessment and evaluation of student performance.

\section{Methodology}

The results presented in this article are based on an exploratory study titled "Cyber journalism from journalism faculties in Colombia", which aimed at studying the perception of the impact of ICTs in the preparation of new professional profiles in journalism as well as the understanding of cyber journalism among professors in journalism departments at universities in Colombia. Within this general objective, one of the specific objectives of this research was to determine the technological profile of journalism professors and how they use ICTs during teaching-learning activities with their students. This article's specific objective is based on two hypotheses to be tested: (1) journalism instructors in Colombia make little use of ICTs in teaching and training their students; (2) journalism instructors in Colombia have a traditional pedagogical model despite advancements in currently existing ICT.

This article is based on a research study consisting of 865 case studies of professors who, during the previously mentioned period, taught at least one academic course offered by a journalism program. In total, the professors belong to 29 journalism departments in Colombia, all of which are members of the Colombian Association of Journalism Faculties and University Programs (AFACOM, initials of the official Spanish title Asociación Colombiana de Facultades y Programas Universitarios de Comunicación). The academic and administrative directors of these departments expressed their interest in participating in this study. Each department that expressed such interest sent lists of the faculty members who belonged to each of the department's academic programs. This was done towards the end of 2008 and during the first trimester of 2009.

A simple random sample was chosen among the professors who belonged to the 29 journalism faculties in Colombia (FCS - Col.), which were analysed in the research upon which the present article is based. The statistical reliability is $90 \%$ and alpha $=$ 0.1. A total of 63 professors were selected and surveyed. All of the samples were collected and processed in the order in which they were received, and the study was carried out from January to April of 2009, when the fieldwork began. The sample was of the minimum sample size accepted in the social sciences, for there was a high nonresponse level among the population under study. This made it difficult to use another type of sample in the research that provides the foundation for this article. 


\section{Results}

\section{Characteristics and technological backgrounds of journalism professors}

In describing the socio-economic profile of journalism professors in Colombia, the data shown in Tables 1 and 2 reveal not only an acceptable degree of reliability in the information obtained for the ordinal variables considered, but also the common characteristics of a member of this population. The average member of the population: (1) earns an average monthly salary of US $\$ 1,600$ (6.35 times the current legal minimum wage established by the Government of Colombia for 2010); (2) holds a mid-range part-time teaching position; (3) has a masters degree, the average education level of the population according to the averages obtained in this project; (4) has been working at the university for 5 or 6 years; and (5) has a profession related to advertising, despite the fact that we observe a variance of 2.919 , which reveals a large degree of variability in the professors' responses with regard to their professional backgrounds.

Table 1: Analysis of salary, position, and education level of journalism professors in Colombia in early 2009

\begin{tabular}{|l|c|c|c|c|c|c|c|}
\hline & \multirow{2}{*}{$\mathrm{N}$} & \multirow{2}{*}{ Min } & \multirow{2}{*}{ Max } & \multicolumn{2}{|c|}{$\begin{array}{c}\text { Average frequency of socio- } \\
\text { economic traits }\end{array}$} & Variance & Alpha \\
\cline { 5 - 8 } & & & & Average & Std. Dev. & & \\
\hline Average salary* & 63 & 1 & 3 & 2.29 & .923 & .853 & .763 \\
\hline $\begin{array}{l}\text { Position held by the inter- } \\
\text { viewee at the end of 2008** }\end{array}$ & 63 & 1 & 3 & 2.29 & .923 & .853 & \\
$\begin{array}{l}\text { Education level of the } \\
\text { interviewee*** }\end{array}$ & 63 & 1 & 5 & 3.73 & .745 & .555 & \\
\hline
\end{tabular}

* Value 1 = approx US\$650 (Min); Value 2 = approx US $\$ 1,600 ;$ Value 3 = approx US\$3,250 (Max).

${ }^{* *}$ Value 1 = Tenured professors (Min); Value 2 = Part time; Value 3 = Full time (Max).

${ }^{* * *}$ Value 1 = Technical degree (Min); Value 2 = Undergraduate degree; Value 3 = Specialisation;

Value $4=$ Masters degree, Value $5=$ Doctorate (Max).

Table 2: Analysis of work experience and professional backgrounds of journalism professors in Colombia in early 2009

\begin{tabular}{|l|c|c|c|c|c|c|}
\hline & \multirow{2}{*}{$\mathrm{N}$} & \multirow{2}{*}{ Min } & \multirow{2}{*}{ Max } & \multicolumn{2}{|c|}{$\begin{array}{c}\text { Average frequency of socio- } \\
\text { economic traits }\end{array}$} \\
\cline { 5 - 6 } & & & & Average & Std. dev. & \\
\hline $\begin{array}{l}\text { Time interviewee has been } \\
\text { working at university* }\end{array}$ & 63 & 1 & 5 & 3.02 & 1.024 & 1.048 \\
\hline $\begin{array}{l}\text { Main profession/degree of } \\
\text { interviewee** }\end{array}$ & 63 & 1 & 5 & 2.13 & 1.709 & 2.919 \\
\hline
\end{tabular}

${ }^{*}$ Min $=1$ (less than one year), Max $=5$ (more than six years).

** Value 1 = Journalism (Min); Value 2 = Advertising; Value 3 = Graphic Design;

Value 4 = Science; Value 5 = Social Sciences and / or Humanities (Max)

With respect to technological backgrounds, the results in Table 3 reveal a clear increase in the use of ICTs among journalism professors in Colombia. This depends on the context in which they are using ICTs. They make less use of ICT at work for professional purposes, whereas they make greater use of ICTs for social purposes, both for their individual social lives as well as their family-related activities. Likewise, we observe that the interviewed professors acknowledge that it is important for them to use ICTs in their teaching activities, even though they generally make little professional and social use of them. 
Table 3: Analysis of ICT use in teaching and social activities among journalism professors in Colombia

\begin{tabular}{|l|c|c|c|c|c|c|c|}
\hline & $\mathrm{N}$ & Min & Max & Average & Std. dev. & Variance & Alpha \\
\hline Weekly ICT use for teaching purposes* & 62 & 1 & 4 & 2.35 & 1.30694 & 1.708 & 0.700 \\
$\begin{array}{l}\text { Weekly ICT use for personal and family- } \\
\text { related purposes * }\end{array}$ & 63 & 1 & 4 & 3.09 & 1.26637 & 1.604 \\
\hline
\end{tabular}

Note: ${ }^{*}$ Min $=1$ (From 1 to 2 times per week); Max $=4$ (More than 6 times per week).

Upon determining which ICT resources are usually employed by journalism professors in Colombia (Table 4), the data allow us to observe how email is the only resource with an average (1.94) that suggests actual use (i.e. is nearest to the "does use" category), whereas the remaining resources, which are usually available in institutions of higher learning, are usually not used by the average journalism professor.

Table 4: Analysis of use of ICT resources by journalism professors in Colombia

\begin{tabular}{|l|l|c|c|c|c|c|c|}
\hline \multicolumn{1}{|c|}{ ICT resource } & $\mathrm{N}$ & Min & Max & Average & Std. dev. & Variance \\
\hline \multirow{2}{*}{$\begin{array}{l}\text { Use of } \\
\text { external ICT } \\
\text { resources }\end{array}$} & Online social networks & 47 & 1 & 2 & 1.34 & .479 & .229 \\
\cline { 2 - 8 } & SMS & 63 & 1 & 2 & 1.03 & .177 & .031 \\
\cline { 2 - 8 } & Podcast & 63 & 1 & 2 & 1.02 & .126 & .016 \\
\cline { 2 - 8 } & Blogs & 63 & 1 & 2 & 1.03 & .177 & .031 \\
\hline \multirow{2}{*}{$\begin{array}{l}\text { Use of } \\
\text { institutional }\end{array}$} & Email & 62 & 1 & 2 & 1.94 & .248 & .061 \\
\cline { 2 - 8 } & Phone calls & 47 & 1 & 2 & 1.32 & .471 & .222 \\
\cline { 2 - 8 } & Catalogue on the subject matter & 24 & 1 & 2 & 1.08 & .282 & .080 \\
\cline { 2 - 8 } & Moodle, WebCT & 63 & 1 & 2 & 1.02 & .126 & .016 \\
\hline
\end{tabular}

Note: $\operatorname{Min}=1$ (does not use); Max = 2 (does use).

Based on the average values presented in Table 4, we can calculate a Technology Use Index (TUI) for journalism professors, using the following formula: TUI $=$ Sum (Average -1$) /($ number of ICT resources), i.e. $1.78 / 8=0.22$. A value of 1 in this index would mean that professors make full use of the institutional and external ICTs that are available to them at their respective universities. The low TUI obtained for journalism professors suggests that they make little use of these resources in their teaching activities.

Table 5: Levels of ICT support device use for teaching purposes

\begin{tabular}{|c|c|c|c|c|c|c|c|}
\hline Support device & $\mathrm{N}$ & Min & Max & Average & Std. Dev. & Variance & Alpha \\
\hline 3G mobile phone & 56 & 1 & 5 & 3.04 & 1.829 & 3.344 & \multirow[t]{15}{*}{0.818} \\
\hline Data projector & 61 & 1 & 5 & 4.00 & 1.017 & 1.033 & \\
\hline Plasma TV & 53 & 1 & 5 & 1.92 & 1.238 & 1.533 & \\
\hline DVD & 57 & 1 & 5 & 3.21 & 1.278 & 1.633 & \\
\hline Digital recorder & 57 & 1 & 5 & 2.47 & 1.351 & 1.825 & \\
\hline Laser pointer & 53 & 1 & 5 & 1.92 & 1.328 & 1.763 & \\
\hline Tablet PC & 53 & 1 & 5 & 1.45 & .972 & .945 & \\
\hline Digital video camera & 58 & 1 & 5 & 2.29 & 1.414 & 2.000 & \\
\hline Low-budget mobile phone & 55 & 1 & 5 & 2.73 & 1.638 & 2.684 & \\
\hline Analog TV & 57 & 1 & 5 & 2.54 & 1.415 & 2.003 & \\
\hline Digital still camera & 54 & 1 & 5 & 2.83 & 1.489 & 2.217 & \\
\hline Laptop computer & 60 & 1 & 5 & 3.82 & 1.308 & 1.712 & \\
\hline Desktop computer & 62 & 1 & 5 & 4.00 & 1.403 & 1.967 & \\
\hline PDA & 50 & 1 & 5 & 1.90 & 1.446 & 2.092 & \\
\hline Interactive whiteboard ('IWB') & 52 & 1 & 4 & 1.27 & .689 & .475 & \\
\hline
\end{tabular}

Data: Min = 1 (no use); Max = 5 (very high use). 
In terms of the use of ICT support devices in the classroom, the averages presented in Table 5 reveal that, with the exception of devices such as desktop computers and data projector, which have an average use of 4 (high use), journalism professors in make little, or moderate to little use, of all other support devices in their classrooms.

Based on the average values presented in Table 5, a Level of Technology Use Index for teaching purposes (LTUIt) may be calculated, using the formula: LTUIt = Sum (Average -1 ) / (number of support devices), i.e. $24.39 / 15=1.63$. This index suggests that they make a low use of these devices when interacting with students in the classrooms.

\section{Factors associated with ICT use}

If we compare the data on the use of ICT resources among journalism professors in Colombia with the demographic data for this population - age, gender, job, monthly salary, career length, education level, position held at the university - the use of ICT is found to have a statistically significant relationship only with the level of importance given to ICT use for teaching purposes (Table 6). This does not mean that there is a positive relationship between ICT use and the degree to which journalism professors in Colombia value them.

Table 6: ICT use in relation to the level of importance of ICT use in the pedagogical activities of journalism professors in Colombia

\begin{tabular}{|c|c|c|c|c|c|c|}
\hline \multirow{2}{*}{\multicolumn{2}{|c|}{$\begin{array}{l}\text { ICT use in teaching } \\
\text { activities }\end{array}$}} & \multicolumn{5}{|c|}{ Level of importance of ICT use in teaching activities } \\
\hline & & \multirow{2}{*}{$\begin{array}{c}\text { Hardly } \\
\text { important }\end{array}$} & \multirow{2}{*}{$\begin{array}{c}\text { Somewhat } \\
\text { important } \\
1\end{array}$} & \multirow{2}{*}{$\begin{array}{c}\text { Important } \\
2\end{array}$} & \multirow{2}{*}{$\begin{array}{c}\begin{array}{c}\text { Very } \\
\text { important }\end{array} \\
16\end{array}$} & \multirow{2}{*}{$\begin{array}{c}\text { Total } \\
19\end{array}$} \\
\hline Once a week & $\mathrm{n}$ & & & & & \\
\hline & $\%$ & $0 \%$ & $5.3 \%$ & $10.5 \%$ & $84.2 \%$ & $100.0 \%$ \\
\hline \multirow[t]{2}{*}{ 1-2 times per week } & $\mathrm{n}$ & 0 & 0 & 2 & 5 & 7 \\
\hline & $\%$ & $0 \%$ & $0 \%$ & $28.6 \%$ & $71.4 \%$ & $100.0 \%$ \\
\hline \multirow[t]{2}{*}{ 3-4 times per week } & $\mathrm{n}$ & 0 & 2 & 3 & 5 & 10 \\
\hline & $\%$ & $0 \%$ & $20.0 \%$ & $30.0 \%$ & $50.0 \%$ & $100.0 \%$ \\
\hline \multirow[t]{2}{*}{ 5-6 times per week } & $\mathrm{n}$ & 0 & 4 & 3 & 6 & 13 \\
\hline & $\%$ & $0 \%$ & $30.8 \%$ & $23.1 \%$ & $46.2 \%$ & $100.0 \%$ \\
\hline \multirow{2}{*}{$\begin{array}{l}\text { More than } 6 \text { times } \\
\text { per week }\end{array}$} & $\mathrm{n}$ & 1 & 4 & 3 & 4 & 12 \\
\hline & $\%$ & $8.3 \%$ & $33.3 \%$ & $25.0 \%$ & $33.3 \%$ & $100.0 \%$ \\
\hline \multirow[t]{2}{*}{ Total } & $\mathrm{n}$ & 1 & 11 & 13 & 36 & 61 \\
\hline & $\%$ & $1.6 \%$ & $18.0 \%$ & $21.3 \%$ & $59.0 \%$ & $100.0 \%$ \\
\hline
\end{tabular}

Note: $\mathrm{N}=63$; tau-c $=0.333 ; \mathrm{p}$-value $=.000$

When analysing the level of importance of ICTs in teaching activities, the only statistically significant relationship found was between the level of importance of ICTs and the education level of the professors who participated in the survey $(p=0.000)$. We thus affirm that, the higher the level of education of the professor, the greater level of importance he/she gives to the use of ICTs in his or her teaching activities.

Considering factors that influence the level of ICTs use in classrooms among journalism professors, 6 factors explain $72.4 \%$ of the series of data used to analyse this section (Table 7):

- Factors related to ICTs used in acquiring and transmitting information in the classroom, whereby greater in-class use of these resources among professors would have a positive effect upon ICTs use in such settings; 
- Factors associated with the latest generation technologies used for communication, whereby the use of PDAs, tablets, and 3G mobile phones would have a positive effect upon ICTs use among professors during their in-class pedagogical activities;

- Factors related to the use of ICTs among professors in their teaching and family-related activities, whereby the increase in the time during which ICT are used for different aspects of professor participation, as well as the use of computers for this same purpose, would have a favorable effect in terms of increased ICTs use;

- Factors related to technology used for in-class dissemination, whereby a greater in-class use of traditional communications resources would favor in-class use of ICTs;

- Factors related to institutional permanence, whereby the more journalism professors are integrated into the university, the more they will use ICTs resources in the classroom; and

- Factors associated with education level, whereby the higher the level of education of professors in journalism departments, the more likely they are to use ICTs in the classroom.

Table 7: Factors associated with the use of ICT among journalism professors in Colombia, in 2008

\begin{tabular}{|c|c|c|c|c|c|c|c|}
\hline \multirow{2}{*}{ Factors } & \multirow{2}{*}{ Matrix of rotating components } & \multicolumn{6}{|c|}{ Components } \\
\hline & & 1 & 2 & 3 & 4 & 5 & 6 \\
\hline \multirow{4}{*}{$\begin{array}{l}\text { Technology used } \\
\text { for acquiring and } \\
\text { transmitting } \\
\text { information in } \\
\text { the classroom }\end{array}$} & Level of digital video camera use for teaching & .824 & & & & & \\
\hline & Level of digital still camera use for teaching & .808 & & & & & \\
\hline & $\begin{array}{l}\text { Level of interactive whiteboard use for } \\
\text { teaching }\end{array}$ & .733 & & & & & \\
\hline & Level of digital recorder use for teaching & .635 & & & & & \\
\hline \multirow{3}{*}{$\begin{array}{l}\text { Latest generation } \\
\text { communications } \\
\text { technology }\end{array}$} & Level of PDA use for teaching & & .817 & & & & \\
\hline & Level of tablet PC use for teaching & & .760 & & & & \\
\hline & Level of $3 \mathrm{G}$ mobile phone use for teaching & & .752 & & & & \\
\hline \multirow{3}{*}{$\begin{array}{l}\text { Professors' use of } \\
\text { ICT for teaching } \\
\text { and family- } \\
\text { related purposes }\end{array}$} & $\begin{array}{l}\text { Weekly ICT use by interviewees for personal } \\
\text { and family-related purposes }\end{array}$ & & & .834 & & & \\
\hline & Level of desktop computer use for teaching & & & .697 & & & \\
\hline & ICT use for teaching purposes during 2008 & & & .675 & & & \\
\hline \multirow{3}{*}{$\begin{array}{l}\text { Technology used } \\
\text { for in-class } \\
\text { dissemination }\end{array}$} & Level of DVD use for teaching & & & & .816 & & \\
\hline & Level of analog TV use for teaching & & & & .661 & & \\
\hline & Level of data projector use for teaching & & & & .651 & & \\
\hline $\begin{array}{l}\text { Institutional } \\
\text { permanence }\end{array}$ & $\begin{array}{l}\text { Time the interviewee has worked at his or } \\
\text { her current university }\end{array}$ & & & & & .861 & \\
\hline Education level & Education level of interviewee & & & & & & .792 \\
\hline \multicolumn{8}{|c|}{$\begin{array}{l}\text { Extraction method: Analysis of the main components. } \\
\text { Rotation method: Varimax with Kaiser normalisation. } \\
\text { Data: } \mathrm{N}=63 ; \mathrm{KMO}=0.598 ; \mathrm{Sig}=.000\end{array}$} \\
\hline
\end{tabular}

\section{Importance of ICTs for teaching}

In determining the usefulness of ICT for teaching activities according to the professors who participated in the survey $(\mathrm{N}=63$ and $\mathrm{n}=62)$, we found that $82.7 \%$ of the survey participants pointed to the "efficiency and dynamism" that ICT offer; while $10.3 \%$ indicated that the importance of ICT lies in the fact that students often use them as learning tools; and $6.8 \%$ of the professors' responses pointed to the ease of access to current and obscure information as well as the enhancement of training and learning that ICT offer when used in teaching. This data reveal how the views held by journalism professors with regard to the usefulness of ICT are centred upon some of 
the main implicit characteristics of these technological advancements: immediacy of communication as well as its capacity to build flexible arenas for communication and information sharing among users, regardless of spatial considerations.

In terms of the importance of ICT use for teaching purposes, the data obtained from the survey participants reveal a context in which journalism professors in Colombia are generally able to acknowledge the use of these resources for educating their students. This is evidenced by the numerical average of responses in this study, which is 4.37. This score falls within the "Important" category, as indicated in Table 8.

Table 8: Importance of ICT for teaching purposes according to journalism professors in Colombia

\begin{tabular}{|l|c|c|c|c|c|c|}
\hline & $\mathrm{N}$ & Min & Max & Average & Std. dev. & Variance \\
\hline Level of importance of ICT use for teaching* & 62 & 1 & 5 & 4.37 & .834 & .696 \\
\hline
\end{tabular}

Data: * Min = 1 (not important); Max $=5$ (very important)

Finally, the analysed data, based on the analysis of a Chi-squared test on the level of importance of the use of different ICT resources (SMS, podcast, email, blogs, online social networks, etc) for teaching purposes, reveals that the only factor that has a statistically significant effect $(p=0.022)$ with respect to the importance of ICT use is the professors' use of SMS. This means that the degree of importance of ICT use for teaching purposes will be greater to the extent that members of the population being studied do or do not use SMS. Accordingly, this allows us to point out that the level of importance of ICT will depend not only on how much universities invest in technology, thus offering a variety of ICT resources and devices for developing teaching-learning dynamics between teachers and students, but rather on whether or not they use mobile devices that will allow them to communicate in real time and at a lower cost through text messages.

\section{Conclusions}

The data analysed allow us to conclude that employment levels and use of ICTs in the teaching activities of Colombian journalism professors should be improved. This is needed notwithstanding the high recognition they accord to the importance and usefulness of these resources, in the development of the teaching-learning processes. Currently, those who are teaching journalism in Colombia do not seem to find the right context to face the challenges coming from advances in ICTs, Web 2.0 and the emergence of new business models for the media in the Internet. The dissemination of content through the Internet in the form of digital journalism or spontaneous forms is changing traditional models of mass communication (Sotelo \& Sierra, 2009), as a result of the integration of new services such as Twitter, Facebook, Flickr, among others) and technological supports (mobile phones, PDAs). For this reason the promotion of educative scenarios which enhance the development of hypertext systems and the use of virtual scenarios for teaching activities (Landow, 2008) would be a key factor favouring the developing of transversal competencies through the application of ICTs, and the promotion of virtual scenarios which strengthen communication students at the moment of describing, explaining and analysing the social scenarios where they will perform as journalists.

Considering factors that influence the use of ICTs for teaching purposes by journalism professors, the data indicate that two variables - the level of acknowledgment of the 
importance of ICT resources and the professor's level of education - significantly influence the extent to which professors make use of these resources (Figure 1). Meanwhile, the level of ICTs use in teaching activities depends on the professor's relationship with students (as one who reveals information, disseminates information, or transmits information in the classroom, or as a communicator), as well as the professor's degree of institutional permanence, education level, and the amount of time the professor has used ICTs both at work and at home (Figure 2).

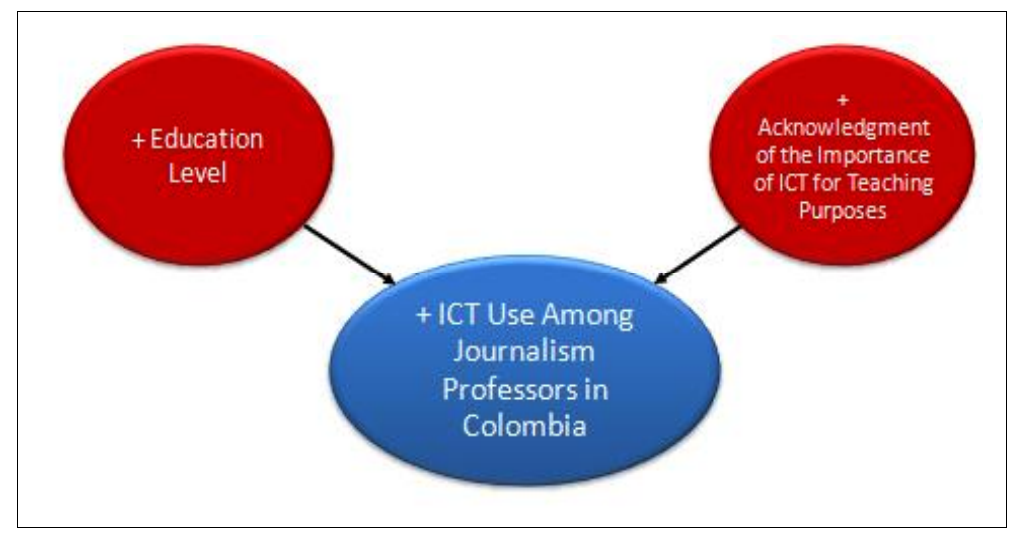

Figure 1: Factors affecting ICT use among journalism professors in Colombia

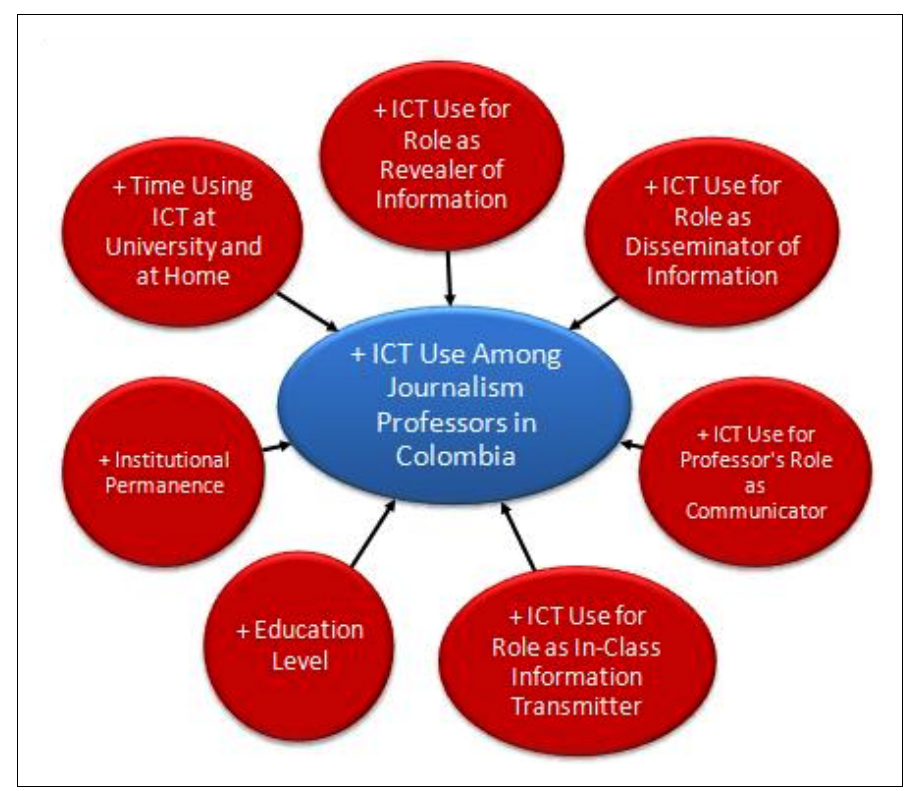

Figure 2: Factors affecting the level of ICT use among journalism professors

The promotion of the use of ICTs among the professors ssampled here will come from the opportunities they have currently for recognising the importance of technological advance in the exercise of their professional work, and their education level. This may be understandable if we relate this to the current demands of institutions of higher 
education, including the series of tasks universities require professors to perform: teach undergraduate and graduate level classes, prepare and participate in academic events, conduct research, and assume specialised administrative roles in the department (as academic director, etc).

The data presented in this article shows a context where the level of use of ICTs by the journalism professors in Colombia may depend on the degree of cross-directional character of academic roles of each professor at the moment of performing a disseminating, divulgating, communicative or knowledge transmitter function from the classroom with the students.

The increase of the levels of use of the ICT resources may be contributing to the transformation of the pedagogical model, where the professor not only has to follow up and support the learning process of the students but also has to promote new scenarios for the acquisition of autonomy in the teaching-learning process in the classroom (Coll, Mauri \& Onrubia, 2006). In this context, the data presented in this article illustrates a scenario where journalism professors require institutional incentives to promote the improving of competencies, which would enable them to take better advantage of technologies for performing their teaching activities, beyond the simple reproduction of traditional pedagogical processes.

Some of the measures or actions to favour the above mentioned could include institutional campaigns to promote the recognition of the importance of ICTs in teaching activities; improving the education levels of professors already employed; enabling professors to acquire competencies not only for the technical knowledge, but also for gettting the best use of new teaching-learning models with more multimedia and hypertexts; strategies to stimulate the level of use of ICTs by professors at institutional and personal/home levels; and finally, institutional mechanisms for technological mediation which stimulate professors to perform their roles as diffusers and disseminating agents, transmitters of knowledge into the classroom from these resources.

The wide gamut of opportunities that the ICTs bring for journalism professors presents a scenario warranting ccontinuing revisision for better development. There is a need to increase the time invested with these professors, to support the constructing and disseminating of journalism education, encompassing both traditional and digital activities.

The class dynamics observed in relations between professors and ICTs show a contemporary scenario, where one can observe an improvement concerning the competencies linked with the technological advances. This is the result of the existing frame of use of technology, which is limiting the possibilities for acquiring competencies which allow professors to describe, explain and analyse learning processes supported by contemporary advances in ICTs. There are difficulties for professors seeking to increase their understanding of social actions from the scenarios and the virtual tools available at social level, and for students needing to acquire these competencies, necessary for their journalism careers, for which they should be wellprepared through their use of technologies in the classroom.

Even though ICTs could improve the quality and efficiency of the education received by journalism students (Westera, 2004), the actions taken by Colombian universities, at least in the case of social communication and journalism programs, are not effecting a 
greater use of ICTs by professors. This leads us to state that the current extent of the use of technologies by professors does not reflect the appearance of referents and models for the management of knowledge, within programs of social communication and journalism in Colombia. and to an even lesser extent the development of hybrid or blended learning processes (Rodriguez \& Escofet, 2006), where different situations and educational media are combined to help improve the learning environment.

Therefore, concepts such as flexibility, mobility, the generation of new types of professors' portfolios (Barberá, et al, 2004), and the increase of the efficiency in the use of pedagogic material through the ICTs, seem to be hindered amongst professors of journalism in Colombia. There are weaknesses in the promotion of more dynamic roles through the use of multimedia and hypertextual resources by students (Landow, 2008, p. 341), and above all, the use of ICTs for learning abilities in educational hypermedia environments (Song, 2002; Kuiper, Volman \& Terwel, 2005; Frechette, 2002).

In spite of what was stated by Landow (2008) when referring to the impact of ICTs in the higher education scenarios, what we have seen in the social communication and journalism programs in Colombia still shows a scenario in which professor-student relations are still dominated by the acquisition, classification, access and exploration of knowledge via a traditional model of literary education. For this reason it would not be convenient to frame the teaching scenarios led by the journalism professors as contexts where their students are being impacted the advances in classroom use of ICTs. If this were so, it would help future journalists in Colombia to acquire of a more self-directed outlook, with advantages that would allow them to assume the set of changes in the ways of production of contents exposed from the traditional media (Palomo, 2004), as well as adopt the new epistemological stance of journalism in the digital era (Haber, 2005)

The lack of penetration and acquisition of technological habits by journalism professors in Colombia is indicating a context which seems to be dominated by a lack of adaptation of the teaching context to new learning scenarios, where social communication and journalism students participate actively in the construction of nonlinear thinking from the virtual scenarios to access information and knowledge currently available (Mayes, Kibby \& Anderson, 1990). If we start with the idea that the advent of a new generation of multimedia and hypertextual students requires professors who are equipped with these characteristics, the data obtained show us that the appearance of this kind of students in the programs of social communication and journalism in Colombia is not happening to date.

To finish it is convenient to say that although the ICTs advances are being applied to a greater or lesser extent in the higher education scenarios in Colombia, the weaknesses found in professors in charge of the education of the future journalists makes the vision presented by Jonassen and Grablinger (1990) seem quite distant: journalism students increasingly responsible for accessing information, sequencing it, and extracting meaning from it.

\section{References}

Bates, A. (1995). Technology, Open Learning and Distance Education. London: Routledge.

Barberá, E., et al (2004). Portfolio electrónico: desarrollo de competencias profesionales en la red. Revista Universitaria y Sociedad del Conocimiento, (3)2, 55-66. 
Castells, M. (2006). La Sociedad Red. Madrid: Alianza Editorial.

Coca, J. (2009). Latinoamérica está 12 veces más lejos de internet que los países desarrollados. Tendencias 21. [viewed 20 Aug 2009, verified 12 Apr 2011]. http:/ / www.tendencias21.net/La tinoamerica-esta-12-veces-mas-lejos-de-Internet-que-los-paises-desarrollados_a3174.html

Coll, C., Mauri, T. \& Onrubia, J. (2006). Análisis y resolución de casos-problema mediante el aprendizaje colaborativo. Revista de Universidad y Sociedad del Conocimiento, 3(2), 29-41. http:/ / www.uoc.edu/rusc/3/2/dt/esp/coll_mauri_onrubia.pdf

Dale, E. (1954). Audio-visual methods in teaching. New York: The Dryden Press.

Departamento Administrativo Nacional de Estadística de Colombia (2005). Censo General 2005. http: / / www.dane.gov.co/ [viewed on 10 Sep 2009].

European Union (2009). The Bologna Process 2020 -The European Higher Education Area in the new decade. [viewed 1 Oct 2009, verified 12 Apr 2011]. http:/ / www.eees.es/pdf/Leuven_Louvain-la-Neuve_Communique_April_2009.pdf

Ferreras, E. (2009). Nuevas herramientas en el ecosistema digital. In J. Flores \& Francisco Estéves (Eds), Periodismo Web 2.0. Madrid: Editorial Fragua.

Fiske, S. \& Taylor, S. (1991). Social cognition. New York: McGraw Hill.

Flores, J. (2008). El “Blog Band” de la información. In J. Flores, M. Cebrián \& F. Estévez (Eds.), Blogalaxia y periodismo en la Red. Estudios, análisis y reflexiones. Madrid: Editorial Fragua.

Frechette, J. (2002). Developing media literacy in cyberspace: Pedagogy and critical learning for the twenty-first century classroom. Westport/London: Praeger.

Fumero, A. \& Roca, G. (2007). Web 2.0. Madrid: Fundación Orange.

Fundación Telefónica (2008). La Sociedad de la Información en España 2008. [viewed on 20 Sep 2009, verified 12 Apr 2011]. http:/ / e-libros.fundacion.telefonica.com/sie08/aplicacion_sie.html

Goffman, E. (1974). Frame analysis: An essay on the organization of experience. Cambridge, Mass: Harvard University Press.

Haber, Y. (2005). El texto periodístico en la era digital. Hacia un nuevo estatuto epistemológico del periodismo. Estudios sobre el mensaje periodístico, 11, 45-52.

Jailler, E. (2009). Internet y la formación de competencias a partir del uso de la prensa on-line. ACORN/REDECOM Conference 2009. http:/ / www.acorn-redecom.org/program.html [viewed 20 Sep 2009, verified 12 Apr 2011].

Jonassen, D. \& Grablinger, R. (1990). Problems and issues in designing hypertext/hypermedia for learning. In Jonassen, D. \& Mamdl, H. (Eds.), Designing hypertext/hypermedia for learning. Heidelberg: Springer-Verlag.

Kuiper, E., Volman, M. \& Terwel, J. (2005). The web as an information resource in K-12 education: Strategies for supporting students in searching and processing information. Review of Educational Research, 75(3), 285-328.

Lamb, R. \& Kling, R. (2003). Reconceptualizing users as social actors in information systems research. MIS Quarterly, 27(2), 197-236.

Landow, G. (2008). Hipertexto 3.0. Barcelona: Paidós. 
Larrondo, A. (2009). La metamorfosis del reportaje en el ciberperiodismo: Concepto y caracterización de un nuevo modelo narrativo. Comunicación y Sociedad, 22(2), 59-88. http:/ / www.unav.es / fcom/comunicacionysociedad/es/articulo.php?art_id=317

Lyotard, J. (1989). The postmodern condition: A report on knowledge. Minneapolis: University of Minnesota Press.

Mayes, T., Kibby, M. \& Anderson, T. (1990). Learning about learning for hypertext. In D. Jonassen \& H. Mandl (Eds.), Designing hypertext/hypermedia for learning. Heidelberg: SpringerVerlag.

Ministerio de Educación, Cultura y Deporte de España (2003). La integración del sistema universitario español en el Espacio Europeo de Enseñanza Superior. España: Author.

Mirón, L. (2007). Las nuevas formulas periodísticas en Internet. In J. Flores (Ed), Blogalaxia y periodismo en la Red. Estudios, análisis y reflexiones. Madrid: Editorial Fragua.

Molenda, M. (2003). Cone of experience, In A. Kovalchick \& K. Dawson (Eds), Educational technology: An encyclopedia. Santa Barbara, CA: ABC-Clio. [viewed 20 Sep 2009; verified 12 Apr 2011, text only]. http:/ / www.indiana.edu / molpage/Cone\%20of\%20Experience_text.pdf

O’Reilly, T. (2006). Qué es Web 2.0. Patrones del diseño y modelos del negocio para la siguiente generación del software. Boletín de la Sociedad de la Información: Tecnología e Innovación. http: / / sociedaddelainformacion.telefonica.es/jsp/articulos / detalle.jsp?elem=2146 [viewed 15 Jun 2008, verified 12 Apr 2011]

Palomo, Ma. (2004). Los nuevos espacios del periodismo digital. In Informe Anual de la Profesión Periodística 2004. Madrid: Asociación de la Prensa de Madrid.

Piscitelli, A. (2002). Cibercultura 2.0. Buenos Aires: Paidós.

Rodriguez, J. \& Escofet A. (2006). Aproximación centrada en el estudiante como productor de contenidos digitales en cursos híbridos. Revista de Universidad y Sociedad del Conocimiento, 3(2), 20-28. [verified 12 Apr 2011] http:/ / rusc.uoc.edu/ojs/index.php/rusc/article/view PDFInterstitial/v3n2-rodriguez-escofet/v3n2-rodriguez-escofet

Said, E. (2009a). Transformaciones comunicativas en la era digital. Hacia el apagón analógico de la televisión. Barranquilla: Ediciones Uninorte.

Said, E. (2009b). Communicative maps and challenges in the digital era. Civitas Revista de Ciências Sociais, 9(1), 19-35. [verified 12 Apr 2011] http:// redalyc.uaemex.mx/ redalyc/pdf/742/74212712003.pdf

San Jose State University (2004). The Dale's Cone of Experience. [viewed 20 Aug 2009, not found 12 Apr 2011]. http://www.sjsu.edu/depts/it/itcdpdf/dale.pdf

Sartori, G. (2002). Homo videns: La sociedad teledirigida. Madrid: Editorial Taurus.

Simon, H. (1955). A behavioral model of rational choice. Quarterly Journal of Economics, 69, 99-118.

Song, C. (2002). Literature review for hypermedia study from an individual earning perspective. British Journal of Educational Technology, 33(4), 435-447.

Sotelo, J. \& Sierra, J. (2009). Un nuevo modelo de comunicación reticular. In J. Flores \& Francisco Estéves (Eds), Periodismo Web 2.0. Madrid: Editorial Fragua. 
Sunkel, G. (2007). Las nuevas tecnologías de la comunicación y la información (TIC) en la educación. Desafíos para las políticas públicas en América Latina. Organización de Estados Iberoamericanos. http: / / www.oei.es / tic/ santillana/sunkel.pdf [viewed 1 Oct 2009, verified 12 Apr 2011].

United Nations Development Programme (2009). Human Development Report 2009. New York: UNDP. http:/ / hdr.undp.org/en/reports/global/hdr2009/chapters /

Westera, W. (2004). On strategies of educational innovation: Between substitution and transformation. Higher Education, 47(4), 501-517.

Westera, W., Sloep, P. \& Gerrissen, J. (2000). The design of the virtual company: Synergism of learning and working in a networked environment. Innovations in Education and Training International, February, 23-33.

World Bank (2009). Country and lending groups - Data. [viewed 20 Sep 2009, verified 29 Mar 2011] http:/ / data.worldbank.org/about/ country-classifications/ country-and-lending-groups

Author: Elias Said Hung $P h D$

Department of Journalism and Observatory of Education for the Caribbean Region of Colombia, Fundación Universidad del Norte

Km. 5 vía Puerto Colombia, Piso 2. Bloque D. Ofic. 2-11D, Barranquilla, Colombia

Email: saide@uninorte.edu.co Web: http:/ / blogs.uninorte.edu.co/saide.php

http:// www.digitalandsociallab.ning.com/

Please cite as: Said, E. (2011). ICT use by journalism professors in Colombia.

Australasian Journal of Educational Technology, 27(2), 259-273.

http: / / www.ascilite.org.au/ajet/ajet27/said.html 